\title{
Incumbency Disadvantages and Populism in Indonesian Local Elections: Case Studies of Banda Aceh and Takalar
}

\author{
Nurlinah $^{1}$, Rizkika Lhena Darwin ${ }^{2}$, and Haryanto ${ }^{3}$
}

Received: 28 September 2018 | Accepted: 25 May 2019 | Published: 18 June 2019

\begin{abstract}
This article seeks to contribute an understanding of how populism informs incumbency disadvantages in elections. Incumbency has been seen as highly beneficial in elections, and many studies have found that incumbent candidates enjoy significant access to resources with which they can campaign. This article, however, finds a different reality, with incumbents in Banda Aceh and Takalar experiencing electoral defeat. In both areas, extensive field studies before and after the local elections found that incumbents' unwillingness to adopt a populist approach during their terms influenced voters' choices. The main argument of this article is that, in Indonesia's local democracies, incumbency has created space for varied models of populism, including the communitarian populism found in Aceh and Takalar. Such populism has emerged from specific socio-cultural contexts at the local level that have shaped voters' preferences. The socio-cultural context of communal societies such as Aceh and Takalar has informed the truth value through which elites, policies, and phenomena are judged. Ultimately, this communitarian populism cannot be separated from the public's desires for elections. These two cases offer a profile of how communitarian societies respond to and shape local populism in Indonesia.
\end{abstract}

Keywords: incumbency; populism; communitarianism; local election

\section{Introduction}

Some questions are asked when an incumbent fails to win an election: why and how has this happened? In many democratic countries, incumbents receive a significantly higher number of

1 Department of Government, Universitas Hasanuddin, Makassar, 90245 Indonesia. Email: nurlinah@unhas.ac.id.

2 Department of Political Science, Ar-Raniry State Islamic University, Banda Aceh, 23111 Indonesia Email: rizkikadarwin@ar-raniry.ac.id.

3 Department of Political Science, Universitas Hasanuddin, Makassar, 90245 Indonesia. Email: harymusi@unhas.ac.id 
votes than non-incumbents, improving their chances for re-election (Campbell, 1983; Gelman \& King, 1990; Anderson \& Glomm, 1992; Carey, Niemi, \& Powell, 2000; Mayhew, 2008). Similar cases have also been found in Indonesia (Lay, Hanif, Ridwan, \& Rohman, 2017; Mas'udi \& Kurniawan, 2017). This can be attributed to the fact that incumbents have access to resources that are unavailable to their challengers. However, in recent years, elections in democratic countries have become increasingly competitive, and as such incumbency can no longer guarantee electoral victory. Several studies have argued that incumbents' electoral defeats are caused by social and political tensions, as in Latin America (Dix, 1984); declining party attachments, congressional-bureaucratic relations, and the rise of new voters, as in the United States (Ansolabehere \& Snyder, 2002; Desposato \& Petrocik, 2003); voters' ideological responses to economic issues, as in Spain (Torcal, 2014); cases of corruption among incumbents, as in Romania (Klasnja, 2015); levels of voter information and economic conditions, as in Africa (Macdonald, 2014); and criminal candidates and voter dissatisfaction with the availability of public goods, as in India (Aidt, Golden, \& Tiwari, 2011; Uppal, 2009).

It can thus be seen that incumbents have some advantages and disadvantages. This article will focus more on the latter. Studies have examined incumbency disadvantages, including those cited above. However, such studies have tended to use institutionalist and behaviouralist perspectives, despite these perspectives being insufficient to explain the phenomenon in democratic politics: through a cultural perspective. As seen in the case of Indonesia, particularly at the local level, incumbents have often faced failure because of three reasons: policy, gender, and corruption. All three of these issues, based on further reflection, have tended to be constructed through a populist approach. As such, through populism, this article seeks to ascertain a perspective that can better explain incumbency disadvantages. Populism may be understood through various approaches, including ideational, political strategy, 
and sociocultural ones. Although these three perspectives have most commonly be used as the conceptual basis for empirical study, we hold that a sociocultural approach is capable of explaining the incumbency disadvantages experienced in Aceh and Takalar. This sociocultural approach is used to explain populism within the context of policy, gender, and corruption.

In Indonesia's 2017 local elections, 37 of the 61 participating incumbents won their elections; in other words, $60.65 \%$ were able to use their advantages as incumbents. The percentage of incumbents who failed to be re-elected (39.35\%), however, was significant, indicating the fruitfulness of investigating the concept of incumbency advantages in elections. We selected two of the incumbents who lost their electoral contestations for further analysis. These incumbents came from different provinces; the first came from Banda Aceh City, Aceh, while the second came from Takalar Regency, South Sulawesi. These two local elections were selected for analysis for several reasons. First, these two areas involved head-to-head electoral contestations between one incumbent and one challenger, easing the identification of candidates' policies/programmes. Second, these elections reflected different issues. Banda Aceh was chosen to consider the issue of gender and incumbency, while Takalar was chosen to examine the issue of corruption and incumbency; further analysis found that, in these two areas, gender and corruption were generally constructed through populism. Finally these areas were chosen as they enabled a comparison of urban and rural areas, from which socio-cultural conclusions could be drawn. In comparative studies, it is necessary to compare two things that produce the same phenomenon despite their differences.

Field research was conducted before and after simultaneous local elections were held in February 2017. Data was collected through in-depth interviews with a number of key informants in both regions, including candidates, party cadres, campaign team members, local activists, village chiefs, and the general public. The researchers also collected data from regional bylaws as well 
as news coverage of the candidates' policies and electoral events. For an understanding of incumbency advantages, the literature on the concept - particularly that related to Indonesian elections - was reviewed. To support this article's argument, the following section will explore the dynamic development of populism within elections around the world. The socio-cultural approach to understanding populism provides the conceptual framework for this study's exploration of incumbency disadvantages. Data from the two regions investigated will be used to support and complement our argument.

\section{Incumbents in Elections}

In the lead-up to elections, incumbents frequently enact policies, implement programmes, and offer financial assistance (including grants) to gather voters' support (Dahlberg \& Johansson, 2002 , p. 27). In distributing funds before elections, incumbents may target two loci: in areas where incumbents already have considerable support (Cox \& McCubbins, 1986) and in areas where swing voters are located (Lindbeck \& Weibull, 1993; Dixit \& Londregan, 1996). Such programmes have similarly been used by incumbents in Indonesia as an electoral strategy (Aspinall \& Sukmajati, 2016), with financial assistance taking the form of cash, public goods, and empowerment programmes. Such a strategy is used in elections at all levels, both national and local, and in both the executive and legislative branches. Such a situation indicates a reciprocal relationship in which patronage is used to gain public legitimacy. It has remained influential even in this era of decentralised local elections, where regional leaders are directly elected through local elections (Mas'udi \& Kurniawan, 2017; Haryanto, 2017; Darwin, 2017).

Below, we present some general conclusions regarding incumbency that deal with issues similar to ours: policy, gender, and corruption. The conceptual framework established by previous 
scholars has been constructed through an institutionalist and behaviouralist perspective. From a behaviouralist perspective, incumbents occupy a significant position, as voters are driven to evaluate candidates based on their prior performance rather than their campaign promises. Under this model, the key to gathering voters' support is not campaign promises, but rather what incumbents have already done for voters (Ferejohn, 1986, p. 6; Uppal, 2009, p. 24).

Meanwhile, an institutionalist perspective has been used by Klasnja \& Titiunik (2017) in discussing the incumbency curse: candidates are expected to be accountable to voters, and incumbents are accountable for their behaviour. The incumbency curse tends to be influenced by political parties' ideologies and their discipline in controlling incumbents' interactions with the public (i.e. voters). This can result in systematic losses for both parties and incumbents, such that the resources they enjoy while in office (as mentioned above) cannot guarantee their re-election. Simply put, voters delegate authority to political parties, and political parties delegate their authority to candidates, with this delegation invoking accountability within a specific time frame and demanding public satisfaction. When politicians, as the representatives of political parties, fail to produce policies that influence voters' preferences, the disadvantages of incumbency tend to dominate.

Within an Indonesian context, behaviouralist and institutionalist perspectives have similarly been dominant (see Savirani \& Törnquist, 2015). The position of incumbents is determined, it has been argued, by whether voters approve of the policies that have been enacted (Savirani, 2015, p. 65). In other words, the more populist a leader, the more he or she is liked; however, this tends to be marked by patronage, in which politicians have direct action to voters without using political parties. Another conclusion has been drawn by Rosenfield (2012) regarding the influence of gender on incumbency and elections in Indonesia. Women incumbents tend to result in higher levels of women's participation in elections, with parties nominating more women 
with more beneficial positions on ballots. According to Rosenfield, women incumbents can persuade voters and parties to re-elect them (Rosenfield, 2012, p. 577). Such a finding is further supported by the case of Latin America (Rosenfield \& Hinojosa, 2014). However, a different situation has been seen in Aceh, where a female incumbent lost the electoral contestation, as will be explained below.

This discussion leads us to the conclusion that incumbents are strongly influenced by their political policies, political parties, as well as socio-cultural conditions such as gender and accountability (as a rejection of corruption). At the same time, it may be seen that there has been an increased tendency for populism. This will be discussed in further detail below, taking examples from both the West and the East.

\section{Populism in Elections}

The rise of populism has frequently been linked to the election of Donald Trump in the United States and the Brexit Referendum in the United Kingdom (Anselmi, 2018). Definitions of populism tend to be diverse but generally, refer to a sort of public desire. Definitions of populism are generally contextual, being influenced by the situation in which populism emerges. In Europe, the rise of populism in elections has been marked by the increased influence of right-wing political parties (Mudde, 2004). European populism has been linked to a specific type of political party, i.e. anti-establishment parties (Hartleb, 2018, p. 13). The opposition of "us" and "them" is characteristic of these parties and is used to gather electoral support. These parties have identified issues of immigration and ethnicity as having a central role in determining the general will. Meanwhile, in Latin America populism has been personified by the charismatic leadership of such individuals as Juan Perón (Argentina), Hugo Chavez (Venezuela), and Getúlio Vargas (Brazil) (Weyland, 2001; Hawkins, 2003). Populism has frequently been used as a label for politicians who aggressively defend the interests of everyday people 
over those of the ruling elites (Acemoglu, Egorov, \& Sonin, 2013, p. 771).

Meanwhile, in Asia (including Southeast Asia) the phenomenon of populism emerged following the monetary crisis of the late 20th century. At the time, populism was dominated by strong and charismatic leadership (Mizuno \& Phongpaichit, 2009; Kenny, 2017). Populist leaders found a place in the crisis, becoming persons who could defend the interests of the common people even as the political parties and elites were corrupt and mismanaged. Over time, through elections, these populist leaders were able to gain the support of voters and win elections. Where in Latin America populism was closely linked to socialism, in Asia populism has generally been affiliated with neoliberalism. In the end, the general conclusion among scholars has been that this populism has been enacted through a top-down and personalistic approach, being enabled by a wide range of ideologies. Populism has also been linked to patronage, as found in many democratic countries around the world (Kenny, 2017).

In Indonesia, studies of populism have historically been uncommon; however, there has been a surge in such studies since the 2014 presidential elections (Mietzner, 2015, p. 54). Scholars have generally focused on specific political actors, identifying populism with populist candidates such as Prabowo Subianto (Aspinall, 2015) and Joko Widodo (Mietzner, 2015; Pratikno \& Lay, 2011; Djani \& Tornquist, 2017), as well as the modus operandi of local elites and their power (Savirani, 2015). Ultimately, these scholars argue that the welfare state campaigns common among Indonesian politicians are indicative of transformative democratic politics. Politicians have become increasingly dependent on populism and charismatic leadership in mobilising public support. They may do so by interacting directly with the public, outside of political parties (Pratikno \& Lay, 2011; Djani \& Tornquist, 2017), by campaigning on nativist and anti-elite platforms (Aspinall, 2015), or by emphasising technocratic public service (Mietzner, 2015). As elsewhere, 
definitions of populism in Indonesia have generally linked it with personalism, charisma, and the mobilisation of the majority.

Studies of populism have produced a wide range of definitions. Some scholars have identified "populism in politics" as a model for the charismatic connection between voters and politicians (Acemoglu et al., 2013). Populism has also been defined as a political strategy (Weyland, 2001), while others have seen populism as a political movement in which a majority develops a political identity without a shared ideology (Laclau, 2005) i.e., a "thin-centred ideology" (Mudde, 2004). Three conceptual approaches to populism have dominated the academic debate: the ideational approach, the political strategy approach, and the sociocultural approach (Kaltwasser, Taggart, Espejo, \& Ostiguy, 2017). The ideational approach holds that populism is a set of ideas that not only depicts society as divided between "the pure people" versus "the corrupt elite", but also claims that politics is about respecting popular sovereignty at any cost (Mudde \& Kaltwasser, 2017, p. 6). Central to the ideational approach are the concepts of ideology, the people, the elite, and the general will (Mudde, 2017). Although populism is defined as a specific set of ideas, the ideational approach distinguishes it from classical ideologies such as fascism and liberalism. As such, populism can exist within any ideology that attracts the general public, as it is based in the public will.

The second approach to populism studies is the political strategy approach. It emphasises personalistic leadership that rests on direct, unmediated, uninstitutionalised support from large masses of mostly unorganised followers (Weyland, 2017, p. 49). This approach tends to emphasise the role of political actors as populist leaders. As it deals directly with the relationship between political actors and their publics, studies using this approach tend to highlight the failure of political linkages within the democratic system, including the failure of political parties to connect state and society. The personal abilities of populist leaders are perceived as being used by populist leaders to mobilise their followers, gain 
power, and ultimately maintain it. Such an approach has been common in studies of populism in Indonesia, including those of Lay \& Pratikno (2011), Mietzner (2014, 2015), Aspinall (2015), and Savirani \& Törnquist (2015).

The final approach to populism studies is the socio-cultural approach. This approach applies a socio-cultural perspective to understand the degree to which populism is accepted (Ostiguy, 2017). As populism emphasises the general will, it is necessary to consider the political linkages between political leaders and their social basis. This can ease the categorisation of "high and low" or "good and bad" reception of shared agreements. Unlike the above approaches, this concept seeks to understand populism as relational, rather than the individual. This is not to say that it ignores the importance of actors; rather, it underscores the fact that acceptance of actors cannot be separated from socio-cultural and politico-cultural contexts (Ostiguy, 2017, p. 74). Two types of sociocultural components shape populism: social-cultural components and politico-cultural components. The first type involves etiquette, behaviour, speech patterns, clothing standards, vocabularies, and tastes, all of which are sociologically constructed and presented to the public. The second type, meanwhile, holds that various aspects of political leadership and policymaking-including personal power (particularly for men), personality (charisma), and technoprocedural capacities - can only be recognised when they are in accordance with contemporary culture. The sociocultural approach holds that populist figures and regimes can only exist where enabled by socio-cultural factors. As such, populism can be explained best through an understanding of the "general will" of the populace, as shaped by local society and culture.

Of these approaches, the most dominant in discussions of populism in Indonesia is the political strategy approach. This article seeks to explore incumbency disadvantages through populism-more specifically, using a socio-cultural approach. This approach has been chosen based on consideration of the 
Indonesian social context, where principles of communitarianism have been reinforced as ideologies have weakened. The incumbency disadvantages studied in this article show different tendencies, including candidates' policy and programmatic politics, gender and Islamic life in Aceh, and corruption in Takalar. However, both cases offer a more comprehensive model of communitarian society's response to and construction of populism, which may benefit or harm incumbents during elections.

\section{Local Elections in Two Areas}

In February 2017, 101 of Indonesia's administrative divisions (provinces, regencies, and cities) held simultaneous elections. These included Banda Aceh, Aceh, and Takalar, South Sulawesi; these areas have been selected because their incumbents were not elected. In the Banda Aceh mayoral election, the incumbent mayoral candidate was Illiza Sa'aduddin Djamal, a woman who had served two terms as deputy mayor as well as a term as mayor; she and her running mate, Farid Nyak Umar, were backed by two local parties (the Aceh Party and Aceh Regional Party) as well as two national parties (the Prosperous Welfare Party and United Development Party). Their opponents, Aminullah Usman and Zainal Arifin, were backed by six national parties: Golkar, National Mandate Party, National Awakening Party, Great Indonesia Movement Party, Crescent Star Party, and the National Democratic Party. Previously, in the 2012 elections, Illiza Sa'aduddin Djamal and Aminullah Usman had competed. However, the results of the election were quite different; in 2017, the incumbents received only 30,207 votes (33.23\%), whereas their challengers received 60,689 votes $(66.77 \%)$.

Illiza Sa'aduddin Djamal had considerable political experience, having previously served as a member of the Banda Aceh Municipal Parliament and the Acehnese Provincial Parliament before becoming deputy mayor. She had also been an active member of the United Development Party (PPP), an Islamic party, since 
2002. She came from a long line of politicians; her grandfather had served as regent in several parts of Aceh, and both her mother and father were active PPP cadres and had been members of the Acehnese Provincial Parliament. Her running mate, Farid Nyak Umar, was a politician with the Prosperous Justice Party (PKS) and had been elected to the Banda Aceh Municipal Parliament in 2014. These incumbents were both from ethnic majorities, tracing their lineage to Aceh Rayeuk and Pidie, respectively. Meanwhile, their challenger Aminullah Usman was the former director for the Acehnese Regional Bank. He was also known for his involvement in football association, having been made the leader of the Banda Aceh Football Team in 2017. His running mate, Zainal Arifin, was a National Mandate Party cadre who had served two terms as a member of the Acehnese Provincial Parliament.

Banda Aceh is a city with a pluralist and open society, an urban region with a diverse populace. Nonetheless, communitarianism is clear in majority-Muslim society. Most of the city's residents are migrants from other parts of Aceh, and as such, it is demographically similar to the rest of Aceh; this reflects the conflict of communitarianism, which Etzioni (2011) identifies as social bonds between members of society that are based in mutual concern and shared core values. In Aceh, religiosity (Islam) is a value that both unites society and shapes social perspectives. This can be seen, for example, in the social structure, which positions both umara (political leaders) and ulama (religious scholars) as elites. The umara are the government leaders and officeholders within a specific jurisdiction and include sultans, rajas, ulee balang, sagoe commanders, mukim, and geuchik.

Meanwhile, ulama are social leaders entrusted with religious affairs (Islamic law) and are known in Acehnese as ureueng nyang malem (devout people). Although the names of these administrative leaders have changed, the hierarchy and underlying structure have not. This socio-cultural situation, as well as the social structure, have provided fertile ground for patronage and populism. In regional 
elections in Aceh, this patronage has even involved the brokerage of women (Darwin, 2017). As such, it is very interesting to consider the electoral defeat of the incumbent in Banda Aceh's mayoral elections within the context of the social, cultural, and structural conditions of Indonesia since political reform began in the late 1990s.

Meanwhile, in Takalar, a regency that borders the provincial capital of Makassar, head-to-head elections also occurred. The incumbent, in this case, was Burhanuddin Baharuddin, who ran together with his deputy Muhammad Natsir Ibrahim. These incumbents were backed by most of the political parties that controlled the regional parliament, namely Golkar, National Mandate Party, Democratic Party, People's Conscience Party, Democratic Party of Indonesia - Struggle, Great Indonesia Movement Party, United Development Party, Indonesian Justice and Unity Party, and Crescent Star Party. The challenger, meanwhile, was Syamsari Kitta. He and his running mate, Achmad Dg Se're, were backed only by two parties: the National Democratic Party and the Prosperous Justice Party. In this election, the incumbent was defeated with a margin of only $1.16 \%$ (2,023 votes).

Burhanuddin Baharuddin was a Golkar cadre who had served as a member of the South Sulawesi Provincial Parliament from 2009 to 2012. Before entering politics, Burhanuddin was an entrepreneur who offered financial consulting services. His running mate, Muhammad Natsir Ibrahim, was a Golkar cadre and the son of a former Regent. The challenger, Syamsari Kitta, was a Prosperous Justice Party member who had long served as a member of the South Sulawesi Provincial Parliament. His running mate, Ahmad Dg Sere, had previously been part of the United Development Party's faction in the People's Representative Council in Jakarta. The two were also united by familial bonds; Ahmad Dg Sere had married the sister of Muhammad Natsir Ibrahim.

This regency, which is located along the southern coast of Sulawesi, is dominated by the fishery sector and another major source of employment in agriculture. Takalar is known as the 
largest producer of fish in South Sulawesi. Similar to other rural parts of Indonesia, Takalar is characterised by homogeneity and agrarianism. As a result, patronage and clientelism are common in all parts of social life, including in elections (Haryanto, 2017).

Although Takalar and Banda Aceh are geographically distinct, and the former is rural while the latter is urban, both have been marked by the practice of patronage in elections. This indicates that both rural and urban parts of Indonesia have similar tendencies in their local electoral processes. Patronage and clientelism have a significant role in determining the results of elections. As argued by Kenny (2017), and mentioned previously, such patronage offers fertile ground for populism. Such populism, in turn, can exacerbate incumbency disadvantages. The following sections will examine how populism shapes election results.

\section{Populist versus Non-Populist Programmes}

Analysis has found that the defeat of these incumbents can be attributed to the policies that they implemented as mayor/regent. "Campaign discounts," to borrow a term from Gordon \& Landa (2009), or "incumbency advantages as an account," to borrow from Mayhew (2008), are inversely related to the results of local elections in Banda Aceh and Takalar. The question, thus, is why incumbents lost. Several of the policies and programmes prepared by incumbents and their challengers have been identified, as can be seen in Table 1 (for Banda Aceh) and Table 2 (for Takalar). In both areas, the political decisions of incumbents - as manifested through policy and programmatic politics - determined their electability.

\section{Banda Aceh}

In Banda Aceh, candidates campaigned on different issues. The policies produced by the incumbent were not particularly populist, unlike those of the challenger. The incumbent's policies were generally perceived as exclusive, symbolic, and discriminating 
against most residents of Banda Aceh. Even in a predominantly Muslim society, where religious symbols are understood and used too strictly, non-populist policies are produced. Table 1 shows how the challenger made use of this issue to promote populist programmes based on participation, humanist Islam, and youth involvement.

\section{Table 1: Populist and Non-Populist Programmes and Policies in the Banda Aceh Election}

\begin{tabular}{|c|c|}
\hline Incumbent & Challenger \\
\hline $\begin{array}{l}\text { Forced eviction and prohibition } \\
\text { of sales along Ulee Lheu Beach } \\
\text { after 6:00 p.m., without any } \\
\text { clear solution, based on a belief } \\
\text { that evening sales will promote } \\
\text { debauchery among visitors }\end{array}$ & $\begin{array}{l}\text { The promise of Rp. } 3 \text { million in funds } \\
\text { to families of deceased; full maternity } \\
\text { packages for new mothers; reopening } \\
\text { of Ulee Lheu Beach to accommodate } \\
\text { merchants. A people's economy, } \\
\text { supported through creative economic } \\
\text { activities }\end{array}$ \\
\hline $\begin{array}{l}\text { Enactment of curfew for women } \\
\text { travelling without a mahram } \\
\text { (unmarriageable kin) }\end{array}$ & $\begin{array}{l}\text { Woman leader discriminating against } \\
\text { other women }\end{array}$ \\
\hline Minimal provision of electricity & \multirow[b]{2}{*}{$\begin{array}{l}\text { Attempt to improve access to basic } \\
\text { facilities such as electricity and water }\end{array}$} \\
\hline $\begin{array}{l}\text { Limited availability of clean water } \\
\text { (through regional government } \\
\text { enterprise) }\end{array}$ & \\
\hline $\begin{array}{l}\text { The tendency for sensational } \\
\text { interpretation of Islamic law: } \\
\text { labelling of deviance, unbelief }\end{array}$ & $\begin{array}{l}\text { Manifesting a "Happy Banda Aceh" } \\
\text { (Banda Aceh Gelimang) through the } \\
\text { implementation of Islamic law }\end{array}$ \\
\hline $\begin{array}{l}\text { The mass mobilisation of school } \\
\text { children to demonstrate against New } \\
\text { Year's Eve celebrations and during } \\
\text { trials of accused unbelievers }\end{array}$ & \multirow[t]{2}{*}{$\begin{array}{l}\text { Provision of a public space for people to } \\
\text { gather, learn, interact }\end{array}$} \\
\hline $\begin{array}{l}\text { Minimal facilities for youths and } \\
\text { public }\end{array}$ & \\
\hline $\begin{array}{l}\text { Islamic teaching and proselytisation } \\
\text { (da'wah) by the foreign ulama }\end{array}$ & $\begin{array}{l}\text { Prioritising local ulama in Islamic } \\
\text { teaching and proselytisation (da'wah) }\end{array}$ \\
\hline
\end{tabular}

The table above highlights the challenger's attempts to seize advantage of the social situation, particularly residents' having tired 
of the incumbent's policies. There was a rejection of the exclusive interpretation of Islam as well as the elitist policies that ignored the public will. To borrow a term from Lauclau (2005), there existed an empty signifier that was used by the challenger.

Within the context of Banda Aceh, this empty signifier cannot be separated from the history of conflict and tsunami experienced in Aceh. Both historical facts strongly influenced the population's understanding of welfare. Following decades of conflict, as well as the devastating tsunami of December 2004, much aid was received by the people of Banda Aceh. Residents became used to receiving aid directly, and many sought immediate results rather than those achieved over the long term. As such, programmes such as financial support for grieving families, maternity packages, and the reopening of Ulee Lheu Beach were perceived as "good," particularly as opposed to the "bad" of prohibiting sales at Ulee Lheu Beach and supporting demonstrations against New Year's Eve celebrations.

\section{Takalar}

Similarly, in Takalar, the policies of the incumbent tended to be less populist than those of the challenger. During his term as regent, the incumbent focused more on building infrastructure and prioritised development in the regency capital over more rural areas. Meanwhile, the challenger offered voters highly populist programmes in order to sway them. The challenger in the election used a total of 22 political promises. The most influential of these included the "cattle card" (provision of cattle to economically needy families); free hajj and umrah pilgrimages for the village imam; free education and healthcare; and marriage subsidies. These 22 programmes were developed based on Samsari's background in agriculture, including in husbandry and fisheries, as well as his membership in the Islamic-oriented Prosperous Justice Party. 
Table 2: Populist and Non-Populist Programmes and Policies in the Banda Aceh Election

\begin{tabular}{|l|l|}
\hline Incumbent & Challenger \\
\hline Sale of state land (corruption) & Cattle aid (one cattle per family) \\
\hline $\begin{array}{l}\text { Placement of government employees } \\
\text { through the Regent's brother }\end{array}$ & $\begin{array}{l}\text { Provision of free ambulances and } \\
\text { garbage services }\end{array}$ \\
\hline Road construction & $\begin{array}{l}\text { Rewarding of village, hamlet, and } \\
\text { mosque imams (hajj and umrah) }\end{array}$ \\
\hline $\begin{array}{l}\text { Prioritisation of capital over rural } \\
\text { areas }\end{array}$ & Free education and healthcare \\
\hline & Marriage subsidies \\
\hline
\end{tabular}

The challenger's programmes were highly populist, and indeed the candidate saw these as important for his campaign. One member of the campaign team, who also led Commission 2 in the Takalar Parliament, explained:

"The topic of programmes, including direct social assistance, could rapidly gain public sympathy. Meanwhile, health and education policies already existed, but still needed to become a programme." (Sulaeman Rate Daeng Laja, interview, April 25, 2018).

Meanwhile, many of the incumbent's campaign promises were seen as unfulfilled. Not a single one of his welfare policies had been implemented.

"There were many promises, such as savings and loans for women, insurance, and whatnot. Many of his supporters have died here, but there has been no (aid). The programmes (of the incumbent) have not taken shape during his time as regent." (H. Hatibu, interview, April 8, 2017).

The above table, as well as the public impressions discussed here, indicate that the policies of the incumbent did not reflect the socio-cultural conditions of Takalar. As in Banda Aceh, there was a discourse of "high versus low," with the incumbent being seen as promoting elitist programmes that ignored the public will.

Briefly, it may be concluded that incumbency advantages were 
dependent on the communitarian populism, with political policies and support being shaped by social perceptions and conditions. These two local elections show a tendency in Indonesian local elections tend to reflect more on social and cultural life, as well as how well it is reflected (or not reflected) in local politicians' policies and programmes.

\section{Gender and Islamic Communitarianism}

The mayoral election in Banda Aceh may be identified as having been dominated by two narratives, namely the quality of public service and religious symbols-particularly the belief that "women may not become leaders." The precept that "women may not become leaders" has been seen as part of Islamic law; as such, Islam has been understood as not allowing women to take leadership roles. The election of Illiza Sa'aduddin Djamal was the first time in history that a woman mayor had been chosen through direct elections. Gender issues have remained common in the province, despite women's leadership having historical precedent. For example, Aceh was led by a series of women sultans (sultana) in the 17 th century.

Similarly, during the late 19th and early 20th centuries, a number of women-led an armed resistance against Dutch colonialism, including Cut Nyak Dhien and Cut Meutia. Similarly, the recent history of conflict and tsunamis in Aceh drove women to participate more as agents, taking leadership roles in their families, communities, and everyday lives (Darwin, 2017). Also present in the region is a regional understanding of Islam that has enabled women to practice agency, such as by leading dayah (Islamic boarding schools) and thereby having the opportunity for equal partnership with men (Srimulyani, 2013).

However, such agency has been politicised through the sociocultural (religious) context of Aceh as well as the social hierarchy with the (male) ulama at the top, thereby reinforcing gender inequality. 
This has posed a serious challenge for female politicians. When women candidates are involved, discourse holding that Islamic law prohibits women's leadership emerges and strengthens inequality. Such a condition is exacerbated when a woman leader is perceived as having produced non-populist policies. This was experienced by Illiza in the 2017 mayoral elections, who was opposed by people who interpreted Verse 34 of Surah An-Nisa as meaning that women cannot lead. Such a view was written on pamphlets and distributed in public spaces, including in the prayer halls of Banda Aceh (FGD, Banda Aceh, 4 March 2017).

The literature has argued that women incumbents enjoy specific advantages that ease their re-election (Rosenfield \& Hinojosa, 2014). Being incumbents allows women candidates to show their leadership capabilities, and as such, enables them to address public pessimism. However, a different situation occurred during the Banda Aceh mayoral election, which showed that female incumbency did not have a positive effect on voters or the parties backing the candidate. Institutionally, the incumbent was backed by four political parties; however, this did not guarantee the personal support of party members. Even the Ulama Council of Nanggroe Aceh, an organisation under the Aceh Party and as such expected to support the incumbent, did not back her. The incumbent also missed the opportunity to gather the support of women.

... Illiza lost a lot of sympathy from the women in the villages, because she did not fulfil the invitations of their prayer groups. Illiza instead travelled out of town to receive an award, even though the campaign was underway. (Syaripah, interview, February 10, 2018).

The above quote highlights another factor that influenced the political decisions of voters. It is difficult for women to become populists, as populism is often identified with male leadership (Mudde \& Kaltwasser, 2017). Populism is identified as masculine; the neo-populism of Latin America is identified particularly closely with machismo (Kampwirth, 2010). Men are perceived as more 
able to seize the moment than women, who are viewed as facing difficulty in making use of electoral momentum. In Banda Aceh, the situation was further exacerbated by the fact that the incumbent had not produced any populist policies to influence voters.

Furthermore, the incumbent was unable to receive the full support of women's movements. As a result, she could not systematically counter the discourse that women may not become leaders. As this discourse spread, women across the spectrum remained silent - even the government-run Women's Empowerment Agency. This too can be attributed to her failure to pass populist policies, which alienated the women voters who made up more than $50 \%$ of the electorate. Several of her policies were seen as unfriendly to women. First was her passage of a curfew for all women except for doctors and teachers. The second was her limited provision of public services to women, particularly those facing lashes for violating Islamic law. Third, the Women's Planning and Action (Musrena) mechanism that had been developed by Iliza had failed to guarantee gender-responsive budgeting and policy; indeed, it was unable to protect its own existence, as less money was allocated for this mechanism every year. Fourth, she had failed to optimally use the balai inong (an agency for empowering women and advocating for their interests) to improve the public position of women. Fifth, merchants in several areas, primarily tourist attractions, were given curfews; this primarily affected women.

In brief, the mayoral election in Banda Aceh was influenced by five categories of non-populist policies, i.e., related to the economy, public facilities, women, youths, and the implementation of Islamic law. These policies primarily affected two segments of the population, who constituted a majority of the electorate: women and youths. In Banda Aceh, a total of 150,608 voters were registered; of these, 76,080 were women, and 74,528 were men. Similarly, young voters represented $40 \%$ of the total electorate. As such, the incumbent's non-populist policies significantly affected her ability to gather political support. This was exacerbated by 
the limited involvement of the political parties backing her, which was significant given the incumbent's subaltern positioning within popular discourse.

Within the context of gender and populism in Aceh, as such, it is evident that the challenger benefited from the socio-cultural situation, particularly its receptiveness to himself as an actor and his arguments. There existed within Aceh an agreement regarding the relationship between religious teachings, women, and leadership. From a socio-cultural perspective, leadership in politics was defined as a male pursuit. Similarly, from a politico-cultural perspective, leadership was identified with personal strength, and as such with men. As such, the binary oppositions of "high versus low" and "good versus bad" ultimately transformed into another one: "male versus female."

\section{Corruption and Political Ethics}

In the case of Takalar, the incumbent was perceived poorly by many members of the electorate. Voter reflection remains an obstacle for incumbents in new democracies, particularly when voters perceive incumbents as corrupt (Klasnja, 2015, p. 928). One incident that significantly affected the electability of the incumbent was the sale of state land, which led to financial losses of Rp 15 billion. This corruption case was soon seized by the incumbent's challenger as a campaign issue. During numerous speeches and debates attended by the authors, supporters of the challenger often shouted slogans are urging voters to "choose a clean leader, not a corrupt one." Burhanuddin was charged with corruption after selling land in Laikang Village, Mangarabombang District, in 2015. This case also included his family, as well as the village and district leaders. In mid-2018, following the incumbent's electoral defeat, Burhanuddin was sentenced to three years and eight months imprisonment by the Criminal Court of Makassar.

Indeed, the incumbent was widely perceived as corrupt 
throughout his term. Rumours also spread that the placement and mutation of government employees (civil servants, subdistrict leaders, teachers, and headmaster) were determined, or at least influenced, by the incumbent's brother; this was indicated in numerous interviews. Several informants also suggested that government positions were being sold. As such, the incumbent's disadvantages came not only from policies but also from corruption. In communitarian societies such as Takalar's, political ethics enables voters to use elections to systematically punish incumbents for corruption, which is perceived as incongruent with society's ethics and culture.

\section{Conclusion: Incumbency and Populism in Local Contexts}

In Indonesia, populism cannot be separated from earlier political culture, which has provided fertile ground for populist leadership. Take, for instance; traditional mechanisms enabled the direct interactions of kings (charismatic leaders) and their subjects. Similarly, under the Old Order electoral narratives were influenced more by tradition than by ideology (Anderson, 2016). As a result, the support and votes received by political parties-nationalist, communist, or religious - during the Old Order era were driven purely by socio-cultural influences (Geertz, 1976). Such a tendency remains common at the local level, informing both leadership and elections (Haryanto, 2017).

In Indonesia, incumbency at the local level has allowed various forms of populism to develop. Incumbents have been identified as important political actors, and populism has been attributed to actors at both the national (Aspinall, 2015; Mietzner, 2015) and local level (Pratikno \& Lay, 2011; Savirani, 2015). However, unlike earlier studies, which have focused on individual actors, the cases of the local elections in Aceh and Takalar show that populism emerges because socio-cultural contexts shape preference for it. In Islamic communitarianism, for example, gender issues can influence public 
discourse about the incumbent. Similarly, a discourse of "elite versus subjugated" can be used to frame an incumbent perceived as failing to behave following social ethics.

In short, there has been a tendency to use communitarian sentiments to promote specific issues during campaigns as well as to draw public attention. Such communitarian populism cannot be separated from the goal of mobilising public support to ensure electoral victory. We have seen that populism is not limited to the national level; it reaches into the local discourse. It may even occupy different democratic spaces at the local level than at the national level. As democratisation has made Indonesian politics increasingly open, different political dynamics have developed throughout the country. The democratisation of Indonesia has promoted communitarian efforts to become involved in democratic life. Where such communitarianism is closely linked to the socio-cultural lives of society, fertile ground exists for the development of contextual populisms at the local level.

\section{Acknowledgements}

An early version of this article was presented at the 3rd International Conference on Social and Political Sciences, UIN Syarif Hidayatullah, Jakarta, on 15 November 2017. 


\section{References}

Acemoglu, D., Egorov, G., \& Sonin, K. (2013). A political theory of populism. The Quarterly Journal of Economics, 128(2), 771-805.

Aidt, T. S., Golden, M. A., \& Tiwari, D. (2011). Incumbents and criminals in the Indian National Legislature. Cambridge Working Papers in Economics 1157. Retrieved from https://ideas.repec.org/p/cam/ camdae/1157.html.

Anderson, B. (2016). Hidup di luar tempurung. Jakarta: Marjin Kiri.

Anderson, S. P., \& Glomm, G. (1992). Incumbency effects in political campaigns. Public Choice, 74(2), 207-219.

Anselmi, M. (2018) Populism: An introduction. Oxon, New York: Routledge.

Ansolabehere, S., \& Snyder, J. M. (2002). The incumbency advantage in U.S. elections: An analysis of state and federal offices, 1942-2000. Election Law Journal, 1(3), 315-338.

Aspinall, E. (2015). Oligarchic populism: Prabowo Subianto's challenge to Indonesian democracy. Indonesia, 99, pp. 1-28.

Aspinall, E., \& Sukmajati, M. (eds.). (2016). Electoral dynamics in Indonesia: Money politics, patronage, and clientelism at the grassroots. Singapore: NUS Press.

Campbell, J. E. (1983). The return of the incumbents: The nature of the incumbency advantage. The Western Political Quarterly, 36(3), 434444.

Carey, J. M., Niemi, R. G., \& Powell, L. W. (2000). Incumbency and the probability of reelection in state legislative elections. The Journal of Politics, 62(3), 671-700.

Cox, G. W., \& McCubbins, M. D. (1986). Electoral politics as a redistributive game. Journal of Politics, 48(2), 370-389.

Dahlberg, M., \& Johansson, E. (2002). On the vote purchasing behavior of incumbent governments. The American Political Science Review, 96(1), 27-40.

Darwin, R. L. (2017). The power of female brokers: Local elections in North Aceh. Contemporary Southeast Asia, 39(3), 532-551.

Desposato, S. W. \& Petrocik, J. R. (2003). The variable incumbency advantage: New voters, redistricting, and the personal vote. American Journal of Political Science, 47(1), 18-32.

Dix, R. H. (1984) Incumbency and electoral turnover in Latin America. Journal of Interamerican Studies and World Affairs, 26(4), 435-448.

Dixit, A., \& Londregan, J. (1996). The determinants of success of special 
interests in redistributive politics. Journal of Politics, 58(4), 11321155.

Djani, L., \& Törnquist, O. (2017). Dilemmas of populist transactionalism: What are the prospects now for popular politics in Indonesia? Yogyakarta: PolGov.

Etzioni, A. (2011). Citizenship in a communitarian perspective. Journal of Ethnicities, 11(3), 336-349.

Ferejohn, J. (1986). Incumbent performance and electoral control. Public Choice, 50(1/3), 5-25.

Geertz, C. (1976). The religion of Java. Chicago: University of Chicago Press.

Gelman, A., \& King, G. (1990). Estimating incumbency advantage without bias. American Journal of Political Science, 34(4), 1142-1164.

Gordon, S. C., \& Landa, D. (2009). Do the advantages of incumbency advantage incumbents? The Journal of Politics, 71(4), 1481-1498.

Hartleb, F. (2018). The rise of new-populism in Europe and Asia. In C. Echle, F. Kliem, \& M. Sarmah (eds.), Panorama: Insights into Asian and European affairs (pp. 9-21) . Singapore: Konrad-AdenauerStiftung.

Haryanto. (2017). Adaptation and continuities in clientelism in a fishing community in Takalar, South Sulawesi. Contemporary Southeast Asia, 39(3), 511-531.

Hawkins, K. (2003). Populism in Venezuela: The rise of chavismo. Third World Quarterly, 24(6), 1137-1160.

Kaltwasser, C. R., Taggart, P., Espejo, P. O., \& Ostiguy, P. (eds.). (2017). Oxford handbook of populism. Oxford: Oxford University Press.

Kampwirth, K. (ed.). (2010). Gender and populism in Latin America: Passionate politics. Pennsylvania: Pennsylvania State University Press.

Kenny, P. D. (2017). Populism and patronage: Why populists win elections in India, Asia, and beyond. New York: Oxford University Press.

Klasnja, M. (2015). Corruption and the incumbency disadvantage: Theory and evidence. The Journal of Politics, 77(4), 928-942.

Klasnja, M. \& Titiunik, R. (2017). The incumbency curse: Weak parties, term limits, and unfulfilled accountability. American Political Science Review, 111(1), 129-148.

Laclau, E. (2005). On populist reason. London: Verso.

Lay, C., Hanif, H., Ridwan, \& Rohman, N. (2017). The rise of uncontested elections in Indonesia: Case studies of Pati and Jayapura. 
Contemporary Southeast Asia, 39(3), 427-448.

Lindbeck, A., \& Weibull, J. (1993). A model of political equilibrium in a representative democracy. Journal of Public Economics, 51(2), 195-209.

Macdonald, B. (2014). Incumbency disadvantages in African politics? Regression discontinuity evidence from Zambian elections. Retrieved from http:// dx.doi.org/10.2139/ssrn.2325674.

Mas'udi, W., \& Kurniawan, N. I. (2017). Programmatic politics and voter preferences: The 2017 election in Kulon Progo, Yogyakarta. Contemporary Southeast Asia, 39(3), 449-469.

Mayhew, D. R. (2008). Incumbency advantage in U.S. presidential elections: The historical record. Political Science Quarterly, 123(2), 201-228.

Mietzner, M. (2014). How Jokowi won and democracy survived. Journal of Democracy, 25(4), 111-125.

Mietzner, M. (2015). Reinventing Asian populism: Jokowi's rise, democracy, and political contestation in Indonesia. Honolulu: East-West Center.

Mizuno, K. \& Phongpaichit, P. (2009). Populism in Asia. Singapore: NUS Press and Kyoto University Press.

Mudde, C. (2004). The populist Zeitgeist. Government and Opposition, 39(4), 541-563.

Mudde, C. (2017). Populism: An ideational approach. In C. R. Kaltwasser, P. Taggart, P. O. Espejo, \& P. Ostiguy (eds.) Oxford handbook of populism (pp. 27-47). Oxford: Oxford University Press.

Mudde, C., \& Kaltwasser, C. R. (2017). Populism: A very short introduction. Oxford: Oxford University Press.

Ostiguy, P. (2017). Populism: A socio-cultural approach. In C. R. Kaltwasser, P. Taggart, P. O. Espejo, and P. Ostiguy (eds.) Oxford handbook of populism (pp. 73-97). Oxford: Oxford University Press.

Pratikno., \& Lay, C. (2011). From populism to democratic polity: Problems and challenges in Surakarta, Indonesia. PCD Journal, 3(1-2), 3361.

Rosenfield, S. S. (2012). The alternative incumbency effect: Electing women legislators in Indonesia. Electoral Studies, 31(3), 576-587.

Rosenfield, S. S., \& Hinojosa, M. (2014). Does female incumbency reduce gender bias in elections? Evidence from Chile. Political Research Quarterly, 67(4), 837-850.

Savirani, A. (2015). Consolidated state, consolidated business actors, and new populist leaders. In A. Savirani and O. Törnquist (eds.), 
Reclaiming the state: Overcoming problems of democracy in post-Soeharto Indonesia (pp. 55-69). Yogyakarta: PolGov and PCD Press.

Savirani, A., \& Törnquist, O. (2015). Reclaiming the state: Overcoming problems of democracy in post-Soeharto Indonesia. Yogyakarta: PolGov and PCD Press.

Srimulyani, E. (2013). Gender in contemporary Acehnese dayah: Moving beyond docile agency? In B. J. Smith \& M. Woodward (eds.), Gender and power in Indonesian Islam: Leaders, feminists, sufis and pesantren selves (pp. 66-80). London: Routledge.

Torcal, M. (2014): The incumbent electoral defeat in the 2011 Spanish national elections: The effect of the economic crisis in an ideological polarized party system. Journal of Elections, Public Opinion \& Parties, 24(2), 203-221.

Uppal, Y. (2009). The disadvantaged incumbents: Estimating incumbency effects in Indian State Legislatures. Public Choice, 138(1/2), 9-27.

Weyland, K. (2001). Clarifying a contested concept: Populism in the study of Latin American politics. Comparative Politics, 34(1), 1-22.

Weyland, K. (2017). Populism: A political-strategic approach. In C. R. Kaltwasser, P. Taggart, P. O. Espejo, \& P. Ostiguy (eds.) Oxford handbook of populism (pp. 47-72). Oxford: Oxford University Press. 